\title{
Muhasebe Öğrencilerinin Hile Alg1s1: Kayseri Üniversitesi Örneği
}

\author{
Arzu MERİฺ̧ \\ $\ddot{\mathrm{O} z}$
}

İşletmelerin faaliyetleriyle ilgili amaçlarına ulaşmasında, en büyük engellerden biri, yapılan hilelerdir. Bu kapsamda işletmelerin en fazla zarara uğradığı ve ortaya çıkarılmasının güç olduğu hileler, muhasebe hileleridir. Hile ile mücadele işletmeler için büyük önem arz etmektedir. Etkin mücadele yöntemlerinin belirlenebilmesi için hile alg1S1 değerlendirmeleri ile başlamak gerekmektedir. Araştırmada muhasebe öğrenimi gören öğrencilerin hile algısını değerlendirmek üzere anket yöntemi ile veriler toplanmış ve elde edilen bulgular analizlerle yorumlanmıştır. Araştırma sonuçlarına göre, öğrencilerin hile alg1sı düşük seviyede belirlenmiştir. Ayrıca yapılan istatistiki analizler sonucu, aileleriyle iyi ilişkileri olan, tek kardeş olan ve inançlı olan öğrencilerin hile algısı daha düşük olarak belirlenmiştir.

Anabtar Kelimeler: Muhasebe Hileleri, Hile Üçgeni, Hile Karosu, Hile Türleri

\section{Perception of Fraud among the Students on Accounting: Example from University of} Kayseri

\section{Abstract}

One of the biggest obstacles in the achievement of the objectives of the businesses related to their activities is Fraud. In this context, the frauds that businesses suffer most and which are difficult to reveal are frauds. Fighting fraud is of great importance for businesses. In order to determine effective fighting methods, it is necessary to start with cheating perception evaluations. In the research, the data were collected with the questionnaire method to evaluate the perception of cheating among the students who studied accounting, and the findings were interpreted with analyzes. According to the results of the research, students' perception of cheating is low. In addition, as a result of the statistical analysis, the perception of cheating of students who have good relationships with their families, who are single brothers and believers is lower.

Key Words: Accounting Fraud, Fraud Triangle, Fraud Dimond, Fraud Types

\section{Atıf İçin / Please Cite As:}

Meriç, A. (2020). Muhasebe öğrencilerinin hile alg1s1: Kayseri üniversitesi örneği. Manas Sosyal Arasttırmalar Dergisi, 9(1), 313-326.

Geliş Tarihi / Received Date: 13.02.2019

Kabul Tarihi / Accepted Date: 18.06.2019 


\section{Giriş}

Muhasebeciler tarafindan yapılan hile eylemleri, iç kontrol sistemince tespit edilmesi güç olan eylemlerdendir. Bu bağlamda, hile eğilimi düşük olan muhasebe çalışanlarının istihdamı, işletmeler için avantaj sağlayabilir. Çalışmada, muhasebe hileleri kavram olarak açıklanmış, hile unsurları olarak; hile üçgeninden hile karosuna doğru bütün unsurlara değinilmiştir. ACFE (Sertifikalı Hile Denetçileri Birliği) hile ağacı ve literatürde işletme odaklı hile türleri açıklanmıştır. Konuyla ilgili yazın araştırması yazılarak, öğrencilere yönelik bir araştırma ile çalışma tamamlanmıştır.

\section{Muhasebe Hileleri}

İngilizce karşıllığ "Fraud" olan hile kavramı, anlamı hasar, yanlış yapma ve aldatma olan "Fraus" sözcügünden türemiştir. Türkiye'deki çalışmalarda, bu kavramın Türkçe karşıllğı olarak hile, yolsuzluk ve suiistimal kavramlarının kullanıldığı bilinmektedir (Batı, 2017, s. 19). Hile kavramı Arapça kökenli bir sözcüktür. Türk Dil Kurumu, hileyi birini aldatmak, yanıltmak için yapılan düzen, dolap, oyun, entrika olarak tanımlamaktadır (www.tdk.gov.tr 26.12.2018). Kavramın tanımlarından bazıları şu şekildedir:

Bir çalışanın çalışı̆̆ı işletmenin kaynaklarını ve varlıklarını kasten uygun olmayan bir şekilde kullanarak veya ele geçirerek haksız kazanç elde etmesidir (Çıtak, 2009, s. 16, Pehlivanl1, 2011, s. 3). İşletme varlıklarıyla ilgili bilgilerin finansal tablolara gerçeği yansıtmayacak bir biçimde yanlış veya eksik yansıtılması başka bir ifadeyle finansal tablolarda yapılan tahrifatlardır (Bayraklı vd., 2012, s. 50). Türkiye İç Denetim Enstitüsü, hileyi; sahte işler peşinden gitmek, güveni kötü amaçlarda kullanarak yasa dışı fiil ve davranışlarda bulunmak şeklinde tanımlamıştır (Özeroğlu, 2014, s. 182).

\section{Hilenin Unsurlar1}

Hilenin unsurları literatürde hile üçgeni olarak ifade edilmekte olup; fırsat, baskı ve haklı gösterme bu üçgenin bileşenleridir. İşletmelerde hilenin nasıl meydana geldiği, bu unsurların incelenmesi ile anlaşlabilmektedir. Her işletme yönetiminin, hile üçgenini ve çalşsanlarının hilenin pek çok çeşidini neden işlediklerini anlamaya ihtiyacı vardır (Terzi, 2012, s. 31).

Donald R. Cressey (1919-1987) doktora tezinde “zimmetine para geçirenleri” seçmiştir ve hapishanelerdeki iki yüz tutuklu ile görüşme yapmıştır. Cressey oluşturduğu hipotezinde, zimmetçileri "güven tecavüzcüleri" olarak tanımlamıştır. Bu hilekârları, işlerini hırsızlık amacıyla kullanan kişiler olarak belirlemiştir. Bu hipotez, ilerleyen yıllarda hile teorisi ve uygulamasında çok önemli bir yere sahip "hile üçgeni” nin ortaya çıkmasına neden olmuştur. Cressey'e göre hile üçgeninin ayakları aşağıdaki unsurlardan oluşmaktadır (Bozkurt, 2011, s. 107): 1) Bask1, 2) Fırsat, 3) Haklı Gösterme.

Cressey tarafindan 1940’ların sonlarında geliştirilen ve hile üçgeni olarak adlandırılan teoriye göre; hilenin işlendiği ortamlarda üç durumun mevcudiyeti söz konusudur (Bayraklı vd., 2012, s. 65). Nitekim, AICPA'ya (Amerikan Sertifikalı Kamu Denetçileri Enstitüsü) bağlı olan Denetim Standartları Kurulu (Auditing Standards Board- ASB) tarafindan yayınlanan SAS (Denetim Standartlar1 Yorumu) No. 99, genellikle bir hile oluştuğunda hile üçgenindeki üç şartın da bulunduğunu ifade etmektedir. Bu şartlar; kişisel finansal problemler veya gerçekleşmesi zor olan hedefler gibi hile işlenmesi için bir baskı, işletmenin iç kontrol sistemindeki eksiklikler gibi bir firsat ve yapılan hileyi haklı göstermek için kişisel bir tutum olarak belirtilmektedir (Free vd., 2007). SAS No: 99'daki yaklaşıma göre, hilenin gerçekleştiği ortamlarda genellikle üç unsurun var olduğu ileri sürülmekle birlikte, hile potansiyelinin oluşabilmesi için hile üçgenindeki tek bir durumun olması da yeterlidir (Küçük ve Uzay, 2009, s. 243).

İşletmede hile ve usulsüzlüğe yönelik baskı veya firsat elde etme veya harekete geçirici olabilecek olay ve koşullar, SPK tebliğinde "hile ve usulsüzlük risk faktörleri”" olarak adlandırılmaktadır. Bu kapsamda (Bayraklı vd., 2012, s. 65):

1. İşletmeye ilave öz sermaye sağlayacak olan üçüncü şahısların beklentilerini karşılama ihtiyacı, hile ve usulsüzlük yapmak için baskı yaratabilir.

2. Gerçekçi olmayan kâr hedeflerine ulaşılması durumunda prim ödemesinin taahhüt edilmesi, hile ve usulsüzlük yapmak için bir teşvik unsuru olabilir.

3. Etkin olmayan kontrol sistemleri, hile ve usulsüzlük yapmaya firsat yaratabilir.

Hile ve usulsüzlük risk faktörleri, mutlaka hile ve usulsüzlüğün olduğunu göstermez. Bağımsız denetçi, hile ve usulsüzlük risk faktörlerinin olup olmadığını ve bu faktörlerin önemli bir yanlışlğga neden olup olmayacağını değerlendirmelidir (Erkan ve Demirel, 2011, s. 33). 
İşletmelerde hileye neden olan unsurlar aşağıdaki alt başlıklarda açıklanmıştır. Önce hile üçgeni olarak ifade edilen bu unsurlar, yetkinlikler unsuru da dikkate alınarak hile karosu olarak ifade edilmiştir. Hile üçgenindeki üç unsur ve üçgeni karoya dönüştüren dördüncü unsur ile ilgili açıklamalara yer verilmiştir.

\section{Baskı ve Motivasyon Unsuru:}

Yönetim veya diğer işletme çalışanlarının, hile yapmaları konusunda kendilerini motive edecek teşviklere sahip olmaları ya da bu konuda baskı altında olmaları olarak ifade edilebilir (Bayraklı vd., 2012, s. 65). Hile eylemi, çalışanı bir şekilde hile yapmaya yönlendiren bir motivasyon ile akla gelmekte veya başlamaktadır. Kişiyi hile yapmaya yönlendiren motivasyon türleri aşağıdaki gibi sınıflandırılabilir (Bozkurt, 2011, s. 113, Terzi, 2012, s. 31):

- Psikolojik Motivasyon: Hirsızlık duygusunun kişinin doğasında var olması.

- Egoya Dayanan Motivasyon: Kişisel prestij sağlamak için hırsızlı̆ga yönelme.

- İdeolojik Motivasyon: İdeolojik nedenlere bağlı olarak morali yükseltmek için ve birini kurban yapmayı haklı görerek hırsızlı̆g yönelme.

- Ekonomik Motivasyon: Ekonomik dürtülerle hırsızlığa yönelme. Bu motivasyon üç ana grupta toplanmıştır:

a) Mali İçerikli Baskılar: Kişilerin çeşitli nedenlerle paraya gereksinim duymaları sonucu ortaya çıkan baskılardır. Mali içerikli baskılara şu örnekler verilebilir: (Bozkurt, 2011, s. 114)

- Para hirsı ve açgözlülük

- Güzel yaşama isteği

- Yüksek tutarlarda kişisel borçlar

- Yüksek tutarlarda sağlık harcamaları

- Yüksek tutarlı eğitim harcamaları

- Beklenmeyen mali gereksinimler

b) Kötü Alışkanlıklardan Doğan Baskılar: Kişinin kumar, uyuşturucu veya alkol bağımlısı olması, gece hayatına düşkünlüğ̈ hileyi tetikleyecek nedenler arasında sayılmaktadır (Bozkurt, 2011, s. 115).

c) İşle İlgili Baskılar: Kişilerin iş yaşamlarında karşılaştıkları olumsuzluklar hileyi tetiklemektedir. Örneğin (Bozkurt, 2011, s. 116):

- Çalışanın işinden memnun olmaması

- Haksızlı̆ga uğradığını düşünmesi

- Beklediği terfiyi alamamasi

- Düşük ücretle çalıştırılması

- Üstlerince gereken takdiri görememesi

\section{Firsat Unsuru:}

İşletmede gerekli kontrollerin yapılmaması ya da etkin olmaması veya yönetimin kontrolleri geçersiz kılma yetenekleri gibi hilenin yapılmasına firsat veren şartların varlığı olarak ifade edilebilir (Bayraklı vd., 2012, s. 65). Bir işletme çalışanının hile yapmaya motive olduktan sonra harekete geçebilmesi için, işletmede olası bir firsatı algılaması gerekmektedir. Fırsat olasıllğını en aza indirme olanağ işletmenin elindedir. İşletme sahip ve yöneticilerinin hile ile mücadelede, müdahale edebildikleri önemli bir unsurdur. İşletmelerde oluşturulacak "İ̧̧ Kontrol Sistemi" firsat unsurunu azaltmada önemli bir etkendir. İşletmelerde hile yapmaya firsat sağlayan etkenler (Bozkurt, 2011, s. 116, Terzi, 2012, s. 31):

- Zayıf bir iç kontrol sistemi

- Uygun olmayan personel politikasi ve yetkilendirme sistemi

- Uygun olmayan bir organizasyon yapısı ve görevlerin ayrillğı ilkesine uyulmamas1

- İç denetim biriminin olmaması veya etkisiz olması

- Zayif bir muhasebe sistemi

- Bağımsız inceleme ve gözlemlerin olmaması

- Fiziki korumaların sağlanmaması

- Belge akış düzeninin olmaması

- Zayıf ahlak politikaları 
- Üçüncü kişilerle ve ortaklarla yapılan gizli anlaşmalar

- Çalışanların yaptıkları işlerin kalitesini değerlendirmede yetersizlik

- Hile yapanların cezalandırılacağı disiplin ortamının sağlanmaması

- Çalışanlar arasında bilgi akışının zayıf olması

\section{Haklı Gösterme Unsuru:}

Hile yapan kişilerin, hileli davranışlarını kendi kişisel etik kuralları ile tutarlı hale getirecek gerekçeler öne sürmeleri olarak ifade edilebilir (Bayraklı vd., 2012, s. 65). Hile üçgeninin üçüncü ayağı, hile yapanın işlediği suçu haklı gösterecek savunma mekanizmaları geliştirmesidir. Hileler sonucu yakalananların kendilerini haklı gösterme gerekçelerinden bazıları (Bozkurt, 2011, s. 121, Terzi, 2012, s. 31):

- Parayı borç almıştım, daha sonra ödeyecektim.

- $\mathrm{Bu}$, işletmeye yaptıklarımın karşıllığıdır.

- Bu olay sonucu hiç kimse incinmedi.

- Bu parayı iyi bir amaç için almışım.

- Yaptığımın suç olduğunu bilmiyordum.

- Bunu herkes yapiyor.

\section{Yetkinlikler Unsuru:}

Donald R. Cressey tarafindan yapılan araştırma sonucu belirlenen ve Joseph T. Wells tarafindan isimlendirilen hile üçgeni, 2004 yilında David T. Wolfe ve Dana R. Hermanson tarafından hile eyleminin olması için var olması gereken ilave bir unsur daha belirtilerek hile karosu kavramına dönüştürülmüştür (Mengi, 2012, s. 113). Söz konusu unsur "yetkinlikler" olarak ifade edilmektedir. Bask1, fırsat gibi unsurların varlığı her zaman kişilerden hileli eylem sonucunu çıkarmamaktadır. Fırsat unsurunu fark etmek, değerlendirmek sonucu hileli eylemi gerçekleştirmek için kişilerin bazı yetkinliklerinin olması gerekmektedir (Olagbemi, 2011, s. 33).

Yetkinlikler, kişilerin görevini yerine getirirken istenilen sonucu elde edebilmeleri için kullanılan bilgi, uygulanan tutum, beceri ve davranış ile sahip olunan değerler ve kişisel özelliklerden oluşmaktadır. Yetkinlikler şu şekilde sınıflandırılabilir (Saruhan ve Yıldız, 2012, s. 148):

a) Başarma eğilimine ve eyleme dönük yetkinlikler: Başarma güdüsü, insiyatif alabilme, risk alabilme, bilgi arama ve edinme çabası, araştırma ve yeniliğe açık olma, düzenli çalışma vb.

b) Yardımlaşma ve hizmete dönük yetkinlikler: Empati kurabilme, kişiler arası ilişkilerde güçlü olma, başkalarını etkileyebilme, güçlü iletișim ve ilişki kurabilme vb.

c) Yönetsel yetkinlikler: Astlarını geliştirme ve eğitme, takım çalş̧ması ve işbirliği, liderlik, yetki kullanabilme vb.

d) Bilişsel yetkinlikler: Analitik düşünme ve problem çözme, kavramsal düşünme ve bütüncül bakış, teknik ve mesleki uzmanlık vb.

e) Kişisel etkililikle ilgili yetkinlikler: Öz kontrol, öz güven, değişime kolay uyum sağlayabilme ve esneklik, örgütsel bağlllık, örgütsel bilince sahip olma ve kurumu tanıma vb.

Hileli eylemi gerçekleştirmek için hilekârın ihtiyaç duyacağ bazı temel yetkinlikler şu şekilde belirtilebilir (Wolfe ve Hermanson, 2004, s. 39):

- Hile eylemini gerçekleştirecek kişinin, iç kontroller ile ilgili zayıf ve eksik olan hususları değerlendirerek kullanabilmesi için zeki olması gerekmektedir.

- Hile eylemini gerçekleştirecek kişinin, planladığı hilenin fayda maliyet analizini yaparak, maliyetinin düşük olacağı bir planı eyleme dönüştürmek için ego sahibi olması ve kendisine güvenmesi gerekmektedir.

- Hile eylemini gerçekleştirecek kişinin, diğer kişileri ya kendisini desteklemeyi ya da hileyi gizlemeyi sağlaması için ikna kabiliyetinin olması gerekmektedir.

- Hile eylemini gerçekleştirecek kişinin, hilenin ortaya çıkarılmasını engelleyebilmek için hile soruşturmacılarına yalan söyleme kabiliyetinde olması gerekmektedir.

- Hile eylemini gerçekleştirecek kişinin, hilenin her an ortaya çıma riski bulunduğundan oldukça uzun bir süre gizliliği sürdürme gibi stresli bir durumla baş edebilmesi gerekmektedir. 


\section{Hile Türleri}

Hileli işlemler literatürde çeşitli şekillerde sınıflandırılmaktadır. Hile türlerinin işletme odaklı olarak sınıflandırılması şu şekildedir (Bozkurt, 2011, s. 65, Terzi, 2012 s. 45):

Çalışan Hileleri: İşletme çalışanının işletme varlıklarına el koyması veya yasa dışı yollarla işverenini dolandırmasıdır. Zimmet yolu ile hırsızlık ya da mesleki hileler olarak da adlandırılmaktadır.

Yönetim Hileleri: İşletmenin mali durumunu olduğundan daha iyi veya daha kötü göstermek ile mali tablolarda yapılan tahrifatlardır. Hileli finansal raporlama ya da finansal tablo hileleri olarak da adlandirilmaktadır.

Yatırım Hileleri: Değersiz veya hiç yapılmayan yatırımların olaydan şüphe duymayan yatırımcılara satılmasidir.

Satıcı Hileleri: İşletmeye mal veya hizmet satanların tek başına veya işletmeden bir çalışan ile işbirliği yaparak gerçekleştirdikleri hilelerdir. Genellikle satın alınan malların yüksek fiyatlandırılması, ikinci kalite malların sevkiyatı, ödemesi yapılmasına rağmen malların sevkiyatının yapılmaması vb. yollarla yapılmaktadır.

Müşteri Hileleri: İşletmeden mal ve hizmet satın alan müşterilerin tek başına veya işletmeden bir çalışan ile işbirliği yaparak gerçekleştirdikleri hilelerdir. Genellikle satın alınan mal bedellerinin ödenmemesi veya değerinin altında ödemeler yapılması, sahip olmadıkları şeyleri vererek şirketi dolandırmaları vb. yollarla yapilmaktadır.

ACFE (Sertifikalı Hile Denetçileri Birliği) hile türlerini bir ağaç modelinde ifade etmiştir. Buna göre, ACFE hile ağacında yer alan hile türleri ise şu şekilde sınıflandırılmaktadır (Terzi, 2012, s. 48):

Varlıkların yanlış kullanımı: Varlıkların kötü amaçlı kullanımı olarak da ifade edilebilen bu hile türü, çalışanlar tarafından en sık yapılan hilelerden olup, işletmeye verilen zarar diğer hile türlerine nazaran düşüktür. Hırsızlık eylemi, işletmenin almadığı mallar için ödeme yapılması, zimmete geçirme gibi şekillerde gerçekleşebilir.

Yolsuzluk: Suiistimal olarak da ifade edilebilen bu hile türü, çalışanlar veya üst yönetim tarafindan yapilmaktadır.

Hileli Finansal Raporlama: Finansal tablo hilesi olan bu hile türü, üst yönetim tarafindan yapılmakta ve az sıklıkta yapılmasına rağmen işletmeye verilen zarar diğer hile türlerine nazaran yüksek tutarlardadır. Raporlamadan kaynaklanan düzensizlikler, mali tablo kullanıcılarını kandırmak için yapılan kasıtlı hatalar veya çeşitli tutarların ihmalidir.

SAS 82'de işletmelerde yapılan hile türlerini açıklamaktadır. Buna göre hileleri iki ana başlıkta toplamak mümkündür (Bayraklı vd., 2012, s. 75): 1) Hileli mali raporlama, 2) Varlıkların haksız kullanımı.

\section{Yazın Araştırması}

Literatürde muhasebe hileleri ile ilgili pek çok çalışma mevcuttur. Öncelikle yapılan kurumsal araştırmalar hakkında bilgiler verilmiştir. Daha sonra bazı akademik çalışmalara değinilmiştir. Bunlardan son yıllarda yapılan kurumsal ve akademik araştırmaların bazıları şu şekildedir:

ACFE (Sertifikalı Hile Denetçileri Birliği), 1996 yllından beri dünya çapında hile konusunda araştırmalar yapan bir kurumdur. 2018 yılında yapmış olduğu hile ile ilgili araştırmaya dünya genelinde 2690 kişi, Türkiye'den 13 kişi katılmıştır. Araştırma sonuçlarından bazıları; hile türü olarak varlıkların kötüye kullanılması \% 89 olup, verdiği zarar 114.000 USD tutarında, yolsuzluk \% 38 olup, verdiği zarar 250.000 USD tutarında, hileli finansal raporlama \% 10 olup, verdiği zarar 800.000 USD tutarındadır. Hilelerin tespit edilme süresi, ortalama 16 ay ve en etkili yöntem $\% 40$ ile ihbarlar olarak belirlenmiştir. Hileye neden olan faktörler olarak da, hilelerin \% 50'sinde iç kontrol zayıflı̆̆ı önemli bir neden olarak belirlenmiştir.

Ernst \& Young, 2016'da 62 ülkeden 2.825 kişinin, Türkiye'den 50 kişinin katılımıyla Hile Araştırması yapmıştır. Araştırma sonuçlana göre, işletmenin belirlediği hedefleri tutturmak için, mali işlerden sorumlu çalışanların \% 42'si, etik dışı davranışlarının olabileceğini belirtmişlerdir. Ayrıca işletmelerine ve çalışma arkadaşlarına sadakat sebebiyle etik dışı davranışları ihbar etme tercihlerinin olmayacağını belirtmişlerdir. 
KPMG, 2016'da Bir Suistimalcinin Profili Araştırması'nı yapmıştır. Araştırma, 81 ülkedeki 750 hile olayı değerlendirilerek yapılmıştır. Hilekârın demografik özellikleri ortaya konulmuştur. Araştırma sonuçlarından bazıları; hile olaylarının \% 65’i işletme içi çalışan tarafından gerçekleştirilmiştir, bunların \% 35 'i ise yönetici ve daha üst pozisyonlarda çalısmaktadır, hile olaylarının \% 79'u erkek ve 36-45 yaş aralı̆̆ındaki kişilerce yapılmıştır.

PwC'nin 2016'da yaptığı Ekonomik Suç Araştırması'na, 115 ülkeden 6.337 kişi katılmıştır. Araştırma sonuçlarına göre, işletme çalışanlarının \% 36'sının hileye karıştı̆̆ı, profil olarak erkek, iyi eğitimli, 31-40 yaş aralığ1, işletmede 3-5 yıldır çalışı̆̆ı gibi sonuçlar belirlenmiştir. Ayrıca hile türlerinden varlıkların kötüye kullanım $1 \% 64$, yolsuzluk ise $\% 24$ olarak belirlenmiştir.

Baird ve Zelin de (2008) çalışanların hile algısı ve raporlama eğilimleri ile ilgili bir araştırma yapmışlardır. Araştırma sonuçlarına göre; çalışanların davranışı onaylaması ile rapor etme eğilimi arasında pozitif yönlü bir ilişsi tespit edilmiş olup, kadınların söz konusu eğilimi erkeklere nazaran daha fazla olduğu belirlenmiştir. Ayrıca hile türlerinden; hileli finansal raporlama uygulamasına, varlıkların kötüye kullanımı ve yolsuzluklara nazaran daha duyarlı oldukları belirlenmiştir.

Aytekin vd. tarafindan (2015) Balıkesir ilinde faaliyette bulunan muhasebe meslek mensuplarının hile belirteçlerine yönelik yaklaşımları araştırılmıştır. Araştırma sonuçlarına göre; kadın meslek mensuplarının erkeklere nazaran daha fazla hile belirteçleri ile karşılaştığı belirlenmiştir. Aynı banka numarası ve posta adresine sahip birden fazla çalışanının olması, bankadan ödendi bilgisi geldiği halde kayitlarda yer almayan çekler, kârlarda açılanamayan azalmalar, faaliyet giderlerinin artması, müşterilere olağan dışı yapılan ödemeler, tahsilatı yapılmayan satışlar, şüpheli alacaklar tutarındaki artışlar gibi hile belirteçleri ile karşılaşıldığı ifade edilmiştir. Ayrıca teknolojik bilgi yetersizliğinin muhasebe hatalarına sebep olduğu ifade edilerek, bu durumun eğitim düzeyi azaldıkça katılımın artması şeklinde bir sonuç verdiği belirlenmiştir.

Aslan vd. (2017) Yalova'da faaliyette bulunan muhasebe meslek mensuplarının hile eğilimi ve mesleki etik konularıyla ilgili algıları değerlendirilmiştir. Araştırma sonuçlarına göre; vergi uygulamaları ve vergi oranlarının, denetim yetersizliğinin hile üzerinde etkili olduğu belirlenmiştir. Katıllımcılar, mesleki etik kurallara uygun davrandıklarını ancak etik dışı davranışlar sonucu verilen cezaların yeterli olmadı̆̆ görüşlerini bildirmişlerdir. Ayrıca, mesleki etik ile ilgili düzenlemelerin yetersizliği ve merkezi bir mesleki etik kurulun olması gerektiği ifade edilmiştir.

Dönmez ve Karausta tarafindan (2011) Akdeniz Üniversitesi, İktisadi ve İdari Bilimler Fakültesi öğrencilerine mesleki hile algısı ve ihbar etme eğilimleri ile ilgili bir araştırma yapılmıştır. Araştırma sonuçlarına göre; mesleki hile algısı ile ihbar etme eğilimi arasında pozitif yönlü bir ilişki tespit edilmiştir. Ayrıca hile türlerinden; hileli finansal raporlama ile varlıkların kötüye kullanımı uygulamalarına daha duyarlı oldukları belirlenmiştir. Kadınların erkeklere nazaran hile eğiliminin ve ihbar etme eğiliminin daha yüksek olduğu belirlenmiştir.

Doğan ve Nazlı (2015), muhasebe hata ve hilelerinin önlenmesinde işletme yönetiminin sorumluluğu ile ilgili bir araştırma yapmışlardır. Araştırma sonuçlarına göre, etkin bir iç kontrol sisteminin, yönetim tarafından hata ve hileli uygulamalar sonucunda cezai yaptırımların olması, yönetimin personelinin eğitim, konferans ve seminerlerle bilgi seviyesini arttırması, işe alım sürecinde özel hayatın irdelenmesi, yöneticilerin dürüst ve ahlaki niteliklere haiz olması gibi hususların hata ve hileli uygulamaları azaltacağ1 belirlenmiştir. Ancak, yönetimin yenilikçi ve esnek olmaması ve muhasebe bilgi yetersizliği gibi unsurların hata ve hileli uygulamaları arttıracağı belirlenmiştir.

Doğan vd. (2018) Adana, Ankara ve Antalya'da faaliyette bulunan muhasebe meslek mensuplarının hile yapmaya eğilim düzeylerinin tespitine yönelik bir araştırma yapmışlardır. Araştırma sonuçlarına göre; katılımcıların, lüks yaşam tercihi, meraklı, risk seven, gizliliği önemseyen, her zaman daha fazlasını elde etmeye çalışan gibi hilekârların bir takım karakteristik özeliklerine sahip oldukları belirlenmiştir.

Gümüş ve Göğebakan (2016) Aydın ilinde faaliyette bulunan muhasebe meslek mensuplarının hile eğilimleri ve etik algıları ile ilgili bir araştırma yapmışlardır. Araştırma sonuçlarına göre; muhasebe hata ve hilelerin mevcut olduğu ve bu durumun etikten sapmalara sebep olduğu belirlenmiştir. Hata ve hileli uygulamalara ve dolayisılla etik sapmalara sebep olarak; mükellefler, hükümet politikaları, vergi uygulamaları, mesleki örgütlenme ve toplumsal yap1 gibi hususlar belirlenmiştir. Katıllımcıların \% 92'si merkezi bir etik kurulun olmasından yana görüş bildirmişlerdir. Ayrıca mükellef istek ve baskılarından hileli uygulamalara başvurduklarını ifade etmişlerdir. Katılımcıların \% 62'si mükelleflerinin karın olduğundan daha yüksek gösterilmesi, \% 59’u giderlerin azaltılması veya gelirlerin azaltılması ve vergi matrahının 
düşürülmesi hususunda baskı altında olduklarını ifade etmişlerdir. Katılımcıların \% 45'i vergi yasalarındaki boşluklardan yararlanmaya çalıştı̆̆ını, \% 40'1 vergi oranlarının yüksek ve enflasyonun yüksek olması sebebiyle hileye başvurabileceğini ifade etmişlerdir.

Özkul ve Özdemir tarafindan (2013) çalşan hilelerinin önlenmesine yönelik kurumsal işletmelerdeki insan kaynakları sorumlularının yaklaşımlarını değerlendirmek üzere bir araştırma yapılmıştır. Araştırma sonuçlarından bazıları; katılımcıların hepsi yaşanan muhasebe skandallarından haberdar olup, üst yönetim ile ilişkili olarak kendilerinin de sorumlu olduklarını belirtmişlerdir. Hileleri önlemeye yönelik olarak işe alım sürecinde özgeçmiş araştırmalarını proaktif bir uygulama olarak belirtmişlerdir. Katılımcıların \% 75 ’i hile vakası ile karşılaştıklarını ifade etmişlerdir ve cesur, zeki, becerikli, izin kullanmayı sevmez, güvenilir, yönetimle iletişimi iyi, borç yükü fazla şeklinde bir hilekâr profili belirleyebilmişlerdir.

Özçelik vd. tarından (2017) Antalya, Isparta ve Burdur'da faaliyette bulunan muhasebecilere yönelik bir araştırma yapılmıştır. Araştırma sonuçlarına göre, mükelleflerinden bilanço kârını düşük gösterme isteklerinin olduğu ve BA-BS formlarının sahte fatura kullanımını azalttığı gibi tespitler yapılmışır. Ayrıca meslek mensuplarınca, hilenin, belgesiz yapılan kayıt dışı işlemler şeklinde ifade edildiği belirlenmiştir.

Ömürbek ve Durgunböcü (2018) Isparta ilinde faaliyette bulunan muhasebe meslek mensuplarının hile algılarının değerlendirildiği bir araştırma yapmışlardır. Araştırma sonucuna göre; meslek mensupları kredi almak için borç ödeme kabiliyetini iyi gösteren ve verginin yüksek olması sebebiyle giderleri arttırmak ve gelirleri azaltmak gibi yöntemlerle mükelleflerinden istek geldiğini ifade etmişlerdir.

Yardımcıoğlu vd. tarafindan (2014) muhasebe hileleri ile ilgili yaptıkları çalışmada, sebep olarak muhasebe sistemindeki mevcut yasal boşluklar tespit edilmiştir. Hilelerin ve yolsuzluğun önlenebilmesi için hukuki düzenlemelere ihtiyaç olduğu belirlenmiştir.

Yılmaz vd. (2018) Türkiye'deki hile denetçilerinin katılımıyla hilelerin ortaya çıkarılması ve önlenmesi yöntemlerini değerlendiren bir araştırma yapmışlardır. Araştırma sonuçlarından bazıları; hile politikası, etik ve davranış politikası, hile risk değerlendirmesi, hile konusunda eğitimler verilmesi gibi hile önleyici tedbirler değerlendirilmiştir ve bu uygulamaların mevcut olduğu işletmelerde daha fazla hileli uygulamaların olduğu belirlenmiştir. Bunun nedeni olarak söz konusu uygulamaların sadece sistemsel olarak var olduğu, ancak etkin mekanizmalar olmadığı belirlenmiştir. İşletmelerde hile yapanların özellikleri olarak; erkek, iyi eğitimli, orta yaş, 6-10 yıllık iş tecrübesine sahip şeklinde tespitler yapılmışıtır.

\section{Araştırma ve Bulgular}

Kayseri Üniversitesi muhasebe öğrencilerinin hile algısını ölçmeye yönelik yapılan araştırma, elde edilen verilere yapılan analizler sonucu bulgular yorumlanarak tamamlanmıştır.

\section{Araştırmanın Amacı, Yöntemi ve Kapsamı}

İşletmelerin en çok zarara uğradığı ve ortaya çıkarılması en zor olan hileler muhasebe birimlerince yapılmaktadır. Araştırmanın amacı; işletmelerin en fazla zarara uğradığı muhasebe hilelerine, muhasebe öğrenimi gören öğrencilerin bakış açısını değerlendirmektir. Araştırma amacına uygun verileri toplamak üzere anket soruları hazırlanmış ve pilot çalışma ile değerlendirildikten sonra Kayseri Üniversitesi'nde muhasebe öğrenimi gören 51 ön lisans, 61 lisans olmak üzere 112 öğrenciye uygulanmıştır. Anket formu, araştırma amacına yönelik iki bölümden oluşmaktadır. Birinci bölümde öğrencilerin genel özelliklerini belirlemeye yönelik 12 soru, ikinci bölümde ise; hile algısını değerlendirmeye yönelik ifadelere katılımın beşli Likert ölçeği ile ölçüldüğü, 7 soru yer almaktadır. Anket öğrencilere uygulandıktan sonra, veriler SPSS paket programına aktarılarak, frekans ve ortalama değerler belirlenmiştir, güvenilirlik, normallik testleri yapılmıştır. Araştırma ile ilgili oluşturulan hipotezlere de istatistiksel analizler uygulanmıştır.

\section{Araştırmaya Katılanların Genel Özellikleri}

Araştırmanın amacına yönelik olarak ankete katılan öğrencilerin genel özelliklerini belirlemek amacıyla birinci bölümde yöneltilen sorulara ilişkin elde edilen bulgular ve frekans dağılımları Tablo 1'de verilmiştir: 
Tablo 1. Katulmmclar Hakekenda Genel Bilgiler

\begin{tabular}{|c|c|c|c|}
\hline Değişken & Düzey & $n$ & $\%$ \\
\hline \multirow{2}{*}{ Cinsiyet } & Kadin & 53 & 47 \\
\hline & Erkek & 59 & 53 \\
\hline \multirow{2}{*}{$\begin{array}{l}\text { Hayatınızın büyük bölümünün geçtiği } \\
\text { yer }\end{array}$} & Köy/Kasaba & 23 & 20 \\
\hline & Şehir Merkezi & 89 & 80 \\
\hline \multirow{3}{*}{ Aile ile ilişkisi } & Kötü & 4 & 5 \\
\hline & İyi & 42 & 37 \\
\hline & Çok iyi & 66 & 58 \\
\hline \multirow{3}{*}{ Aile dışı insanlarla ilişki } & Kötü & 3 & 3 \\
\hline & İyi & 73 & 65 \\
\hline & Çok iyi & 36 & 32 \\
\hline \multirow{2}{*}{ İnançlı bir kişi misiniz? } & Evet & 106 & 95 \\
\hline & Hayır & 6 & 5 \\
\hline \multirow{3}{*}{ Kardeş sayısı } & Yok & 2 & 2 \\
\hline & 1 & 22 & 19 \\
\hline & 2 ve daha fazla & 88 & 79 \\
\hline \multirow{4}{*}{ Arkadaş sayısı } & Yok & 3 & 4 \\
\hline & 1 & 1 & 1 \\
\hline & $2-5$ & 29 & 25 \\
\hline & 5'ten fazla & 79 & 70 \\
\hline \multirow{3}{*}{ Aylık ortalama harçlık } & 300TL ve daha az & 48 & 42 \\
\hline & $301-500 \mathrm{TL}$ & 38 & 33 \\
\hline & 501 TL ve daha fazla & 26 & 25 \\
\hline \multirow{2}{*}{ Bölümünüzü seviyor musunuz? } & Evet & 79 & 70 \\
\hline & Hayır & 33 & 30 \\
\hline \multirow{3}{*}{ Bölümünüz ile ilgili düşünceniz } & Kötümser & 13 & 12 \\
\hline & Kararsiz & 42 & 38 \\
\hline & İyimser & 57 & 50 \\
\hline \multirow{2}{*}{ Muhasebeci olmak istiyor musunuz? } & Evet & 65 & 58 \\
\hline & Hayır & 47 & 42 \\
\hline Toplam & & 257 & 100,0 \\
\hline
\end{tabular}

Ankete katılan öğrencilerin \%53'ü erkek, \%47'si kadındır. \% 79'unun kentli olduğu, \% 95'nin aile ilişkileri iyi düzeyde, \% 97'sinin ailesi dışındaki bireylerle ilişkileri iyi düzeyde olduğu belirlenmiştir. Bu kapsamda katılımcıların sorunlu, geçimsiz kişiler olmadı̆̆ı söylenebilir. Katılımcıların \% 94’ü inançlı öğrencilerdendir. \% 78’i 2 ve daha fazla kardeş sahibi, \% 95’i 2 ve daha fazla arkadaş sahibidir. Katılımcıların sorumluluk bilincinin gelişmesine katkı sağlayan sosyal bir ortamda olduğu söylenebilir. Harçlık düzeyi olarak katılımcıların \% 42'sinin düşük bir gelir düzeyi ile öğrenimini sürdürdüğü belirlenmiştir. Katılımcıların \% 70’i okuduğu bölümü sevmekte, \% 50'si bölümüyle ilgili iyimser düşüncede, \% 58’i muhasebeciliği meslek olarak yürütmeyi düşünmektedir. Bu bağlamda geleceğine muhasebe mesleği ile yön verecek ve muhasebeye ilgi duyan öğrencilerle anket yapma avantajı sağlandığını söyleyebiliriz. Başka bir ifade ile araştırma amacına uygun bir hedef kitle ile yapılmıştır.

\section{Güvenilirlik Analizi Sonuçları}

Toplamda 112 öğrenciye uygulanan ankete güvenilirlik analizi yapılmış ve Cronbach’s Alpha değeri 0,907 olarak belirlenmiștir. Elde edilen değer, ankete verilen cevapların yüksek derecede güvenilir kabul edilebileceğini göstermektedir. Güvenilirlik katsayıları, hile algısını değerlendirmeye yönelik ankette yer alan her bir ifadeye yönelik değerlendirildiğinde; en düşük katsay1 0,884 olarak, en yüksek katsay1 0,900 olarak belirlenmiştir. $\mathrm{Bu}$ değerlerden, ankette yer alan hile algisını değerlendirmeye yönelik ifadelere verilen yanıtların da yüksek derecede güvenilir kabul edilebileceği ifade edilebilir.

\section{Frekans ve Ortalamalara İlişkin Bulgular}

Ankette katılımcıların hile algısını değerlendirmeye yönelik ifadelere ilişkin katılım gösterenlere (katıllyorum ve kesinlikle katıllyorum şeklinde görüş bildirenlere) ilişkin frekans ve ortalama değerler aşağıdaki tabloda verilmiştir: 
Tablo 2. Frekans ve Ortalamalar

\begin{tabular}{cccccc}
\hline Soru numaras1 & $\boldsymbol{N}$ & $\boldsymbol{\%}$ & Ortalama & Standart Sapma & Grup Ort. \\
\hline Soru 1 & 5 & 10 & 1,5446 & 1,00349 & \\
Soru 2 & 8 & 16 & 1,8125 & 1,13528 & \\
Soru 3 & 10 & 20 & 1,8571 & 1,15359 & 1,6779 \\
Soru 4 & 6 & 12 & 2,1696 & 1,34826 & 1,36203 \\
Soru 5 & 8 & 16 & 2,0982 & 1,28750 & \\
Soru 6 & 4 & 8 & 2,0000 & 1,28837 & \\
Soru 7 & 3 & 6 & 1,8750 & \\
\hline
\end{tabular}

Ankette ögrencilere bir firmanın çalışanı olarak, aşağıda ifade edilen muhasebe hilelerine yönelik önermelere katılım düzeyleri beşli Likert ölçeği ile değerlendirilmiştir. Öğrencilerden katılım düzeyini "kesinlikle katılıyorum- kesinlikle katılmıyorum" aralığında derecelendirmeleri istenmiştir:

Soru 1: Önemli bir maddi sıkıntı içerisindeyken ödünç olmak üzere işyerimden izinsiz nakit kullanmamda bir sakınca yoktur.

Soru 2: İşyerimin karşıladığı bazı harcamalarımı mislisiyle göstermemde bir sakınca yoktur.

Soru 3: İşyerimdeki eşya veya ürünleri kişisel faydam için kullanmamda bir sakınca yoktur.

Soru 4: Firmanın tedarikçilerinden ve müşterilerinden kendime yakın hissettiklerimin menfaatini korumaya çalışırım.

Soru 5: Tedarikçilerden ve müşterilerden kendi kişisel menfaatlerim için taleplerim olabilir.

Soru 6: Bankadan kredi çekmek için firma gelirlerini arttıran ve giderlerini azaltan kayıtların yapılmasında bir sakınca yoktur.

Soru 7: Daha az vergi ödenmesi için firma gelirlerini azaltan ve giderlerini arttıran kayıtların yapılmasında bir sakınca yoktur.

Ankette hile algısını değerlendirmeye yönelik ifadelere öğrencilerin katılım düzeyi 1,6779'dur. Bu değere göre, öğrencilerin hile algısının düşük olduğu söylenebilir. Hile algısının değerlendirilmesine yönelik ifadelere "kesinlikle katılmıyorum" şeklinde görüş bildirilmiştir. Katılımcılar, "Firmanın tedarikçilerinden ve müşterilerinden kendime yakın hissettiklerimin menfaatini korumaya çalışıım” şeklideki ifadeye 2,1696 düzeyinde bir görüss bildirmişlerdir. Bu değer yanıtlar içerisinde en yüksek değer olarak, ancak yine "katılmıyorum" şeklindeki görüşü ifade etmektedir. Katılımcılar, "Önemli bir maddi sıkıntı içerisindeyken ödünç olmak üzere işyerimden izinsiz nakit kullanmamda bir sakınca yoktur" şeklindeki ifadeye 1,5446 düzeyinde bir görüş bildirmişlerdir. Bu değer ise yanıtlar içerisinde en düşük değer olarak "kesinlikle katılmıyorum" şeklindeki bir görüşü ifade etmektedir.

\section{Hipotezlere Yönelik İstatistiki Analiz Sonuçları}

Bu aşamada, ankette belirlenen özellikler ile hile algısına ilişkin oluşturulan hipotezler test edilmiştir. Araştırma konusuyla ilgili oluşturulan hipotezler aşağıdaki gibidir:

H1 = Kadın ve erkeklerin hile algısı düzeyleri arasında farklılık vardır.

$\mathrm{H} 2=$ Köylü ve kentlilerin hile alg1sı düzeyleri arasında farklılık vardır.

H3 = Yaşlıların hile algısı düzeyleri gençlere göre farklılık göstermektedir.

H4= Öğrencilerin aile ilişkileri ile hile algısı düzeyleri farklılık göstermektedir.

H5 = Öğrencilerin aile dışındaki kişilerle ilişkiler ile hile algısı düzeyleri farllık göstermektedir.

H6= Öğrencilerin kardeş sayıları ile hile algısı düzeyleri farklılık göstermektedir.

H7 = Öğrencilerin arkadaş saylları ile hile algısı düzeyleri farklılık göstermektedir.

H8= Öğrencilerin aylık harçlıkları ile hile alg1sı düzeyleri farklılık göstermektedir.

H9= Bölümünü seven öğrenciler ve sevmeyen öğrenciler ile hile alg1sı düzeyleri arasında farklılık vardir.

H10= Bölümüyle ilgili düşünceler ile hile alg1sı düzeyleri farklılık göstermektedir. 
H11 = Muhasebeci olmak isteyen ve istemeyen öğrenciler ile hile alg1sı düzeyleri arasında farkll1ık vardir.

H12= İnançlı ve inançlı olmama ile hile algısı düzeyleri arasında farklılık vardır.

Oluşturulan hipotezlere ilişkin yapılan testler ile ilgili tablolar ve test bulguları ile ilgili açılamalar tablonun altında sırasıyla yer almaktadir.

Tablo 3. Cinsiyete Göre T testi

\begin{tabular}{llccc}
\hline \multicolumn{1}{c}{ Cinsiyet } & $\boldsymbol{N}$ & Ortalama & Standart Sapma & Std. Sapma Ort.. \\
\hline Kadın & 53 & 2,7547 &, 62221 &, 08547 \\
Erkek & 59 & 3,0463 &, 47355 &, 06165 \\
\hline
\end{tabular}

T testi sonucuna göre, kadın ve erkeklerin ile hile algisı düzeyleri arasında anlamlı bir farkllık bulunmamaktadır ( $\mathrm{t}=-2,807 ; \mathrm{p}=0,160)$. Sonuç olarak, $\mathrm{H} 1$ hipotezi reddedilmiştir.

Tablo 4. Yaşa Göre ANOV A Analizi

\begin{tabular}{lccccc}
\hline & Kareler Toplam 1 & DF & Ortalama kare & F & Sig. \\
\hline Gruplar Ara. & 2,342 & 9 &, 260 &, 800 &, 617 \\
Gruplar halinde & 33,170 & 109 &, 325 & & \\
Toplam & 35,512 & 111 & & & \\
\hline
\end{tabular}

ANOVA testi sonucuna göre, yaşlı öğrencilerin, genç öğrencilere kiyasla hile algisı düzeyleri arasında anlamlı bir farklılık olmadığı tespit edilmiştir $(\mathrm{F}=, 800 ; \mathrm{p}=0,617)$. H2 hipotezi reddedilmiştir.

Tablo 5. Yerlesim Yerine Göre T testi

\begin{tabular}{llccc}
\hline \multicolumn{1}{c}{ Yerlessim yeri } & $\boldsymbol{N}$ & Ortalama & Standart Sapma & Std. Sapma Ort.. \\
\hline Kasaba & 23 & 2,8725 &, 49845 &, 10393 \\
Kent & 89 & 2,9176 &, 58396 &, 06190 \\
\hline
\end{tabular}

T testi sonucuna göre, kasabada ve kentte yaşayan öğrencilerin hile algısı düzeyleri arasında anlamlı bir farklilık bulunmamaktadır ( $\mathrm{t}=-, 340 ; \mathrm{p}=0,240)$. Sonuç olarak, H3 hipotezi reddedilir.

Tablo 6. Harcliğa Göre ANOVA Analizi

\begin{tabular}{lccccc}
\hline & Kareler Toplam 1 & DF & Ortalama kare & F & Sig. \\
\hline Gruplar Ara. &, 839 & 9 &, 419 & 1,319 &, 272 \\
Gruplar halinde & 34,673 & 109 &, 318 & & \\
Toplam & 35,512 & 111 & & & \\
\hline
\end{tabular}

Anova testi sonucuna göre, öğrencilerin aylık harçlık düzeyleri ile hile algisı düzeyleri arasında anlamlı bir farklılık olmadığ1 tespit edilmiştir $(\mathrm{F}=1,319 ; \mathrm{p}=0,272)$. H4 hipotezi reddedilmiştir.

Tablo 7. Aile ile Olan Ilişkilere Göre ANOV A Analizi

\begin{tabular}{lccccc}
\hline & Kareler Toplam1 & DF & Ottalama kare & F & Sig. \\
\hline Gruplar Ara. &, 990 & 9 &, 495 & 2,020 &, 044 \\
Gruplar halinde & 11,764 & 109 &, 245 & & \\
Toplam & 12,754 & 111 & & & \\
\hline
\end{tabular}

ANOVA testi sonucuna göre, öğrencilerin aileleriyle olan ilişki düzeylerine göre hile algisı düzeyleri arasında \% 99 güven aralığında anlamlı düzeyde bir farklılık bulunmaktadır $(F=2,020 ; \mathrm{p}=, 044)$. Post hoc testlerinden Tukey sonuçlarına göre aile ile ilişkisi kötü olan katılımcıların, aile ile ilişkisi çok iyi olan katılımcılara göre hile algısı yüksektir. H5 hipotezi kabul edilmiştir.

Tablo 8. Sosyal Çevre İle Olan Ilişkilere Göre ANOV A Analizi

\begin{tabular}{lccccc}
\hline & Kareler Toplami & DF & Ortalama kare & F & Sig. \\
\hline Gruplar Ara. & 1,131 & 9 &, 566 & 2,336 &, 108 \\
Gruplar halinde & 11,623 & 109 &, 242 & & \\
Toplam & 12,754 & 111 & & & \\
\hline
\end{tabular}

ANOVA testi sonucuna göre, öğrencilerin sosyal çevreleri ile olan ilişki düzeylerine göre hile algisı düzeyleri arasında anlamlı bir farklılık olmadığı tespit edilmiştir ( $\mathrm{F}=2,336 ; \mathrm{p}=, 108)$. H6 hipotezi reddedilmiştir. 
Tablo 9. Kardeş Sayısına Göre ANOVA Analizi

\begin{tabular}{lccccc}
\hline & Kareler Toplam 1 & DF & Ortalama kare & $F$ & Sig. \\
\hline Gruplar Ara. & 1,181 & 9 & 1,181 & 2,290 &, 037 \\
Gruplar halinde & 25,262 & 109 &, 516 & & \\
Toplam & 26,443 & 111 & & & \\
\hline
\end{tabular}

ANOVA testi sonucuna göre, öğrencilerin kardeş sayılarına göre hile alg1sı düzeyleri arasında \% 99 güven aralığında anlamlı düzeyde bir farklılık bulunmaktadır ( $F=2,290 ; p=, 037)$. Post hoc testlerinden Tukey sonuçlarına göre, 2 veya daha fazla kardeşi olan katılımcıların, hiç kardeşi olmayan katılımcılara göre hile alg1sı yüksektir. H7 hipotezi kabul edilmiştir.

Tablo 10. Arkeadas Sayısına Göre ANOVA Analizi

\begin{tabular}{lccccc}
\hline & Kareler Toplam1 & DF & Ortalama kare & $F$ & Sig. \\
\hline Gruplar Ara. &, 469 & 9 &, 235 &, 433 &, 651 \\
Gruplar halinde & 25,974 & 109 &, 541 & & \\
Toplam & 26,443 & 111 & & & \\
\hline
\end{tabular}

ANOVA testi sonucuna göre, öğrencilerin arkadaş sayılarına göre hile alg1sı düzeyleri arasında anlamlı bir farklılık bulunmamaktadır $(F=, 433 ; \mathrm{p}=, 651)$. H8 hipotezi reddedilmiştir.

Tablo 11. Bölümü Sevme Durumu T testi

\begin{tabular}{lcccc}
\hline \multicolumn{1}{c}{ Yerlessim yeri } & $\boldsymbol{N}$ & Ortalama & Standart Sapma & Std. Sapma Ort.. \\
\hline Seven & 79 & 2,7924 &, 55685 &, 06265 \\
Sevmeyen & 33 & 3,1859 &, 49124 &, 08551 \\
\hline
\end{tabular}

T testi sonucuna göre, bölümünü seven öğrenciler ve sevmeyen öğrencilerin hile alg1s1 düzeyleri arasında anlamlı bir farklılık bulunmamaktadır ( $\mathrm{t}=-3,524 ; \mathrm{p}=0,671)$. Sonuç olarak, H9 reddedilir.

Tablo 12. Bölümle İlgili Düsünceye Göre ANOV A Analizi

\begin{tabular}{lccccc}
\hline & Kareler Toplam 1 & DF & Ortalama kare & $F$ & Sig. \\
\hline Gruplar Ara. &, 067 & 9 &, 033 &, 061 &, 941 \\
Gruplar halinde & 26,376 & 109 &, 549 & & \\
Toplam & 26,443 & 111 & & & \\
\hline
\end{tabular}

ANOVA testi sonucuna göre, öğrencilerin bölümüyle ilgili düşünceleri ile hile alg1sı düzeyleri arasında anlamlı bir farklılık bulunmamaktadır $(\mathrm{F}=, 061 ; \mathrm{p}=, 941)$. H10 hipotezi reddedilmiştir.

Tablo 13. Mubasebeci Olma İsteği İle T testi

\begin{tabular}{llccc}
\hline \multicolumn{1}{c}{ Yerlesim yeri } & $\boldsymbol{N}$ & Ortalama & Standart Sapma & Std. Sapma Ort.. \\
\hline İsteyen & 65 & 1,6088 &, 76735 &, 09518 \\
İstemeyen & 47 & 2,1337 & 1,04614 &, 15260 \\
\hline
\end{tabular}

$\mathrm{T}$ testi sonucuna göre, muhasebeci olmak isteyen ve istemeyen öğrenciler ile hile alg1sı düzeyleri arasında anlamlı bir farklılık bulunmaktadır ( $\mathrm{t}=-3,065 ; \mathrm{p}=0,001)$. Sonuç olarak, H11 kabul edilir.

Tablo 14. Inanca Göre T Testi

\begin{tabular}{ccccc}
\hline Yerlesim yeri & $\boldsymbol{N}$ & Ortalama & Standart Sapma & Std. Sapma Ort.. \\
\hline İnançlı & 106 & 1,7803 &, 87090 &, 08459 \\
İnançsız & 6 & 2,6905 & 1,49671 &, 61103 \\
\hline
\end{tabular}

T testi sonucuna göre, kendilerini inançlı ve inançsız ifade eden öğrencilerin hile alg1sı düzeyleri arasında anlamlı bir farklılık bulunmaktadır ( $\mathrm{t}=-2,387 ; \mathrm{p}=0,035)$. Tablodaki değerlerin $\% 5$ anlamlılık seviyesinde inançsız katılımcıların ortalama cevaplarının (2,6905), inançlı katılımcıların cevaplarından $(1,7803)$ büyük olması sebebiyle, inançsız katılımcıların hile algısının daha yüksek olduğu ifade edilebilir. Sonuç olarak, H12 hipotezi kabul edilir.

\section{Sonuç}

İşletmeler, etkin hile mücadele programlarını belirlemeden önce, hile eğilimi düşük olan çalışanı istihdam etme sorumluluğunu yerine getirmelidir. Nitekim her firsatta hile yapan veya firsat bulduğunda hile yapan çalışan sayısı önemli düzeydedir. Hile ile mücadeleye bu sayıyı azaltmakla başlanmalıdır. 
Geleceğin muhasebecileri olarak muhasebe öğrencilerinin, muhasebe hilelerine bakış açlarını değerlendiren bu araştırmada, hile algisı düşük seviyelerde belirlenmiştir. Muhasebe hileleri kapsamında en düşük kattlım "Önemli bir maddi sıkıntı içerisindeyken ödünç olmak üzere işyerimden izinsiz nakit kullanmamda bir sakınca yoktur" şeklindeki ifadeye olmuştur. Öğrenciler muhasebe hilesi olarak bu önermeye "kesinlikle katılmamak" şeklinde görüş bildirmişlerdir. Muhasebe hileleri kapsamında en yüksek katılım "Firmanın tedarikçilerinden ve müşterilerinden kendime yakın hissettiklerimin menfaatini korumaya çalışırım" şeklindeki ifadeye olmuştur. Öğrenciler muhasebe hilesi olarak bu önermeye "katılmıyorum" şeklinde görüş bildirmişlerdir. Ayrıca öğrencilerin katılım durumu ile aileleriyle ilişkileri, kardeş sayıları ve inanç durumları arasında yapılan testler sonucu anlamlı farklılıklar tespit edilmiştir. Buna göre; aileleriyle iyi ilişkileri olan, tek kardeş olan ve inançlı olan öğrencilerin hile alg1sı daha düşük olarak belirlenmiştir.

Yapılan araştırma sonucuna göre, hile algısı düşük olarak belirlenen öğrencilerin, mesleki hayatlarında hile eğilimine yönelmemeleri için; gerekli etik ve kültürel ortam oluşturulmalı ve rutin eğitimlerle hile eğiliminden caydıran etik ve kültürel ortama bağlılığın sağlanması gerekmektedir.

\section{Kaynakça}

ACFE (2018). Report to the Nations 2018 Global Study on Occupational Fraud and Abuse, https://www.acfe.com

Aslan, T., Kızıl, C. ve Din, A. (2017). Muhasebe hata ve hileleri üzerinde etkili faktörlerin muhasebe meslek etiği kapsamında analizi: Yalova örneği. Journal of Social and Humanities Sciences Research, 4(5), 1125-1138.

Aytekin, S., Sezgin, H. ve Yalçın, M. (2015). Uygulamacıların muhasebede hata ve hileler ile hile belirteçlerine yönelik yaklaşımları: Balıkesir ili örneği. Muhasebe ve Denetime Bakış Dergisi, Ocak, 69-89.

Baird, J. E. ve Zelin, R. C. (2008). Understanding employee perceptions of fraudulent activities and their propensity to report those activities using anonymous tip lines: The influence of fraud type, propetrator gender and observer demographics. Southern Business Review, 33, 1-14.

Batı, M. (2017). Muhasebe hileleri ve vergiden kaçınma. Ankara: Seçkin Yayınevi.

Bayrakl1, H. H., Erkan, M. ve Elitaş, C. (2012). Muhasebe ve vergi denetiminde muhasebe hata ve hileleri. Bursa: Ekin Basım Yayın Dağıtım.

Bozkurt, N. (2011). İsletmelerin kara deliği hile, çalışan hileleri. İstanbul: Alfa Basım Yayım Dağıtım Ltd. Şti.

Çıtak, N. (2009). Hileli finansal raporlamada yaratıcı mubasebe. İstanbul: Türkmen Kitabevi.

Doğan, Z., Gülçin, K. ve Nazlı, E. (2018). Muhasebe meslek mensuplarının hile yapmaya eğilim düzeylerinin tespitine ilişkin bir araştırma. Ömer Halisdemir Üniversitesi İktisadi ve İdari Bilimler Fakültesi Dergisi, 11(4), 64-83.

Doğan, Z. ve Nazlı, E. (2015). Muhasebe hata ve hilelerinin önlenmesinde işletme yöneticilerinin sorumluluğunun tespitine yönelik bir araştırma. Niğde Üniversitesi İIBF Dergisi, 8(4), 195-212.

Dönmez, A. ve Karausta, T. (2011). Çalışanların mesleki hile algısı ve ihbar hattı kullanarak rapor etme eğilimleri üzerine Akdeniz üniversitesi iktisadi ve idari bilimler fakültesinde yapılan bir araştırma. ISMMMO Mali Çözüm Dergisi, Mart-Nisan, 17-42.

Erkan, M. ve Demirel, N. A. (2011). Hata ve hile denetimi: Sermaye piyasası kurulu'na kayıtlı halka açık şirketlere ilişkin düzenlemeler. Muhasebe ve Denetime Bakıs, 10(33), 2-43.

Ernst \& Young (2016). Global Fraud Survey, https:// fraudsurveys.ey.com/

Free, C., Macintosh, N. ve Stein, M. (2007). Management controls: The organizational fraud triangle of leadership, culture and control in Enron. Ivey Business Journal, July- August.

Gümüş, U. T. ve Göğebakan, H. (2016). Muhasebe hata ve hileleri ile muhasebe mesleğinde etik, Aydın ilinde muhasebeciler üzerine bir araştırma. Uluslararası İsletme, Ekonomi ve Yönetim Perspektifleri Dergisi, 1(3), 12-27.

KPMG (2016). Bir suiistimalcinin profili. https://assets.kpmg.com

Küçük, E. ve Uzay, Ş. (2009). Hileli finansal tabloların oluşumu ve doğurduğu sorunlar. Erciyes Üniversitesi İIBF Dergisi, 32, 239-258.

Mengi, B. T. (2012). Hile denetiminde yetkinliklerin değerlendirilmesi- hile karosu. İSMMMO Mali Çözüm Dergisi, Kasim- Aralik, 113-128.

Olagbemi, F. O. (2011). The effectiveness of federal regulations and corporate reputation in mitigating corporate accounting. USA: Xlibris Corporation.

Ömürbek, V. ve Durgunböcü, Ö. (2018). Muhasebe meslek mensuplarının muhasebe hata ve hileleri ile ilgili algilarının incelenmesi. Süleyman Demirel Üniversitesi, İktisadi ve İdari Bilimler Fakültesi Dergisi, 23(4), 1251-1265.

Özeroğlu, A. İ. (2014). Finansal aldatmaca ve işletme hileleri. Akademik Sosyal Araștırmalar Dergisi, 2(2), $180-196$.

Özçelik, H., Aracı, Ö. N. K. ve Keskin, S. (2017). Muhasebe hata ve hileleri: Meslek mensupları üzerine bir araştırma. Süleyman Demirel Üniversitesi, Sosyal Bilimler Enstitüsü Dergisi, 29, 197-214.

Özkul, F. U. ve Özdemir, Z. (2013). Çalışan hilelerinin önlenmesinde proaktif yaklaşımlar: Kurumsal işletmelerde insan kaynakları yöneticileri üzerine nitel bir araştırma. Öneri Dergisi, 10(40), 75-89.

Pehlivanl, D. (2011). Hile denetimi metodoloji ve raporlama. İstanbul: Beta Basım Yayım ve Dağıtım A.Ş.

PwC (2016). Global Economic Crime Survey, https://www.pwc.com

Saruhan, Ş. C. ve Yıldız, M. L. (2012). Insan kaynaklar yönetimi. İstanbul: Beta Basım Yayım Dağıtım A.Ş.

Terzi, S. (2012). Hileli finansal raporlama önleme ve tespit. İstanbul: Beta Basım Yayım Dağıtım A.Ş. 
Türk Dil Kurumu Türkçe Sözlük, http://tdk.gov.tr

Wolfe, D. T. ve Hermanson, D. R. (2004). The fraud diamond: Considering the four elements of fraud. The CPA Journal, 74, 38-42.

Yardımcıoğlu, M., Koca, N., Günay, Y. ve Kocaman, H (2014). Yolsuzluk, muhasebe hileleri ve örnekleri. Kahramanmaras Sütçü Imam Üniversitesi, İ̈BF Dergisi, 4(2), 171-188.

Yılmaz, G., Ataman, B. ve Ayboğa, H. (2018). Hilenin tespit edilmesi ve önlenmesindeki yöntemlerin değerlendirilmesi: Türkiye araştırması. Finans Ekonomi ve Sosyal Arastırmalar Dergisi (FESA), 3(3), 646-664.

\section{EXTENDED ABSTRACT}

Fraud conducted is one of the big obstacles at attainment of the objectives about business enterprises' activities. In this regard, accounting fraud is respected as the most damaged for business and the most difficult being detected. Fight against fraud has a large importance for business. For determining efficient fight against fraud, it is needed to start with evaluating fraud perception. And also before determining efficient anti-fraud programme, caution is warranted to employ personnel whom tendency of fraud is low. Because significance level of fraud that is at every turn as well as when you have the opportunity is large number. It is necessary to start anti- fraud action by minimalizing the number.

In this research so as to determining fraud perceptions of students studying accounting, data were collected by survey method and the results obtained were interpreted. In the questionnaire, the level of participation in the propositions for accounting frauds, which are stated below, as a employee of a firm was evaluated with a 5-point Likert scale. The students were asked to rate the level of participation in the range of "strongly agree- strongly disagree".

According the research that evaluated perceptions of fraud among accounting students as accountants of the future, perception of fraud determined at the lowest level. In the questionnaire, the level of participation of students in expressions aimed at evaluating the perception of fraud is 1,6779. According to this value, it can be said that students' perception of fraud is low. "I strongly disagree" was expressed for the statements regarding the assessment of fraud perception.

Within the scope of accounting fraud, the lowest attendance is for the question as "There is no harm in using unauthorized cash from my workplace on the condition of borrowing when I am in significant financial difficulty". The students replied as "I strongly disagree" for this question as an accounting fraud. The participants expressed an opinion at the level of 1,5446 to the statement as "There is no harm in using unauthorized cash from my workplace on the condition of borrowing when I am in significant financial difficulty". This value is the lowest value of the answers and "I strongly disagree" was expresses as an opinion.

Within the scope of accounting fraud, the highest attendance is for the question as "I try to protect the interests of those close to me from the company's suppliers and customers". The students replied as "I disagree" for this question as an accounting fraud. The participants expressed an opinion at the level of 2.1696 to the statement as "I try to protect the interests of those who feel close to me from the suppliers and customers of the company". This value is the highest value of the answers and "disagree" was expressed as an opinion.

The other statements and their evaluation by the students as below:

The students expresses an opinion at the level of 1,8125 for the statement as "There is nothing wrong with showing some of my expenses in business".

The students expresses an opinion at the level of 1,8571 for the statement as "There is no harm in using goods or products in my workplace for personal benefit".

The students expresses an opinion at the level of 2,0982 for the statement as "I may have requests from suppliers and customers for my personal interests".

The students expresses an opinion at the level of 2,000 for the statement as "In order to take credit from the bank, there is no harm in making records that increase firm revenues and reduce expenses".

The students expresses an opinion at the level of 1,8750 for the statement as "In order to pay less taxes, there is no harm in making records that reduce firm revenues and increase expenses". 
In sum, according to the results, perception of fraud among students determined at the lowest level. In addition, significant differences were found between the participation status of the students and their relationships with their families, the number of siblings and their beliefs. According to this, it is determined that students who are single brothers who have good relations with their families and who have faith have a lower tendency to fraud.

According to the results of the research, the students whose perception of fraud was found low, in order to prevent the tendency towards fraud in their professional life; the necessary ethical and cultural environment which discourages the tendency to fraud should be established. Routine training should be ensured for commitment to the ethical and cultural environment which discourages the tendency to fraud. 